\title{
MELT RATE IMPROVEMENT FOR DWPF MB3: Foaming Theory and Mitigation Techniques (U)
}

\author{
D.K. Peeler \\ T.H. Lorier \\ Westinghouse Savannah River Company \\ Savannah River Technology Center \\ Aiken, SC
}

\author{
J.D. Vienna \\ Pacific Northwest National Laboratory \\ Richland, WA
}

TTP\#: SR-1-6-WT-31

TTR\#: HLW/DWPF/TTR-00-0044, Rev. 0

\footnotetext{
Westinghouse Savannah River Company

Savannah River Technology Center Aiken, SC 29808
}

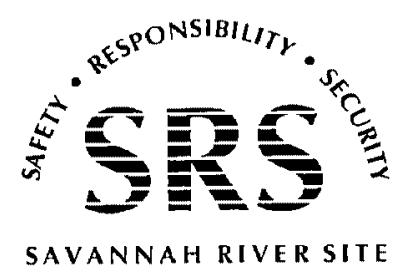

PREPARED FOR THE U.S. DEPARTMENT OF ENERGY UNDER CONTRACT NO. DE-AC09-96SR18500 
This document was prepared in conjunction with work accomplished under Contract No.

DE-AC09-96SR18500 with the U.S. Department of Energy.

\section{DISCLAIMER}

This report was prepared as an account of work sponsored by an agency of the United States Government. Neither the United States Government nor any agency thereof, nor any of their employees, makes any warranty, express or implied, or assumes any legal liability or responsibility for the accuracy, completeness, or usefulness of any information, apparatus, product or process disclosed, or represents that its use would not infringe privately owned rights. Reference herein to any specific commercial product, process or service by trade name, trademark, manufacturer, or otherwise does not necessarily constitute or imply its endorsement, recommendation, or favoring by the United States Government or any agency

thereof. The views and opinions of authors expressed herein do not necessarily state or reflect those of the United States Government or any agency thereof.

This report has been reproduced directly from the best available copy.

Available for sale to the public, in paper, from: U.S. Department of Commerce, National Technical Information Service, 5285 Port Royal Road, Springfield, VA 22161, phone: (800)

553-6847, fax: (703) 605-6900, email: orders@ntis.fedworld.gov online ordering: http://www.ntis.gov/ordering.htm

Available electronically at http://www.doe.gov/bridge

Available for a processing fee to U.S. Department of Energy and its contractors, in paper, from: U.S. Department of Energy, Office of Scientific and Technical Information, P.O. Box 62, Oak Ridge, TN 37831-0062, phone: (865 ) 576-8401, fax: (865) 576-5728, email: reports@ adonis.osti.gov 


\title{
MELT RATE IMPROVEMENT FOR DWPF MB3: \\ Foaming Theory and Mitigation Techniques (U)
}

\author{
D.K. Peeler \\ T.H. Lorier
}

Westinghouse Savannah River Company

Savannah River Technology Center

Aiken, SC

\section{J.D. Vienna}

\section{Pacific Northwest National Laboratory} Richland, WA

This report was prepared by Westinghouse Savannah River Company (WSRC) for the United States Department of Energy under Contract No. DE-AC09-96SR18500 and is an account of work performed under that contract. 


\begin{tabular}{|c|c|c|c|}
\hline Task Title: Improve Melt Rate & & $\begin{array}{l}\text { TTR Number: } \\
\text { HLW/DWPF/TTR- } \\
\text { 00-0044, Rev. } 0\end{array}$ & $\begin{array}{l}\text { TTR Date: } \\
10 / 24 / 00\end{array}$ \\
\hline $\begin{array}{l}\text { Task Leader: } \\
\text { D.K. Peeler }\end{array}$ & Sig afure: $v_{a x}$ & $\begin{array}{l}\text { Organization: } \\
\text { ITS }\end{array}$ & Date: $8-9$ \\
\hline $\begin{array}{l}\text { Task Leader: } \\
\text { J.D. Vienna }\end{array}$ & Sigpature: & $\begin{array}{l}\text { Organization: } \\
\text { PNNL }\end{array}$ & $5 / 15 / 01$ \\
\hline $\begin{array}{l}\text { Task Leader: } \\
\text { T.H. Lorier }\end{array}$ & & $\begin{array}{l}\text { Organization: } \\
\text { ITS }\end{array}$ & $\begin{array}{l}\text { Date: } \\
5-9-01\end{array}$ \\
\hline $\begin{array}{l}\text { Technical Reviewer: } \\
\text { D.P. Lambert }\end{array}$ & & $\begin{array}{l}\text { Organization: } \\
\text { ITS }\end{array}$ & $\begin{array}{l}\text { Date: } \\
5-22-01\end{array}$ \\
\hline $\begin{array}{l}\text { Reviewer: } \\
\text { D.C. Witt }\end{array}$ & & $\begin{array}{l}\text { Organization: } \\
\text { ITS }\end{array}$ & $\begin{array}{l}\text { Date: } \\
5 / 22 / 01\end{array}$ \\
\hline $\begin{array}{l}\text { Level } 3 \text { Manager: } \\
\text { E.W. Holtzscheiter }\end{array}$ & sivolotzahute & $\begin{array}{l}\text { Organization: } \\
\text { ITS }\end{array}$ & $\begin{array}{l}\text { Date: } \\
5 / 10 / 01 \\
\end{array}$ \\
\hline $\begin{array}{l}\text { Level } 4 \text { Manager: } \\
\text { S.L. Marra }\end{array}$ & $\begin{array}{l}\text { Signafure: } \\
\text { Shougn Mama }\end{array}$ & $\begin{array}{l}\text { Organization: } \\
\text { ITS }\end{array}$ & $\begin{array}{l}\text { Date: } \\
\text { 5/10/0) }\end{array}$ \\
\hline
\end{tabular}


Immobilization Technology Section

Savannah River Technology Center

Rev. 0

Westinghouse Savannah River Company

\section{GLOSSARY}

DOE U.S. Department of Energy

DTA differential thermal analysis

DWPF Defense Waste Processing Facility

INEEL Idaho National Environmental and Engineering Laboratory

MB3 Macrobatch 3

MS mass spectrometer

SRTC Savannah River Technology Center

TGA thermogravimetric analysis

TFA Tanks Focus Area

THERMO Thermodynamic Hydration Energy Reaction Model 
Immobilization Technology Section

Savannah River Technology Center

Rev. 0

Westinghouse Savannah River Company

This page intentionally left blank. 


\section{ACKNOWLEDGMENTS}

The authors would like to acknowledge Denny Bickford, Carol Jantzen, Dan Lambert, Mike Stone, and Douglas Witt (SRTC) and Pavel Hrma (PNNL) for their technical guidance and reviews, and William Holtzscheiter (TFA TIM for Immobilization) and Sharon Marra for management and guidance. This study was co-funded by the Department of Energy's Office of Science and Technology through the Tanks Focus Area and through the Defense Waste

Processing Facility. Westinghouse Savannah River Company is operated for the U.S. Department of Energy under Contract No. DE-AC09-96SR18500. 
Immobilization Technology Section

Savannah River Technology Center

Rev. 0

Westinghouse Savannah River Company

\section{Contents}

\section{GLOSSARY}

ACKNOWLEDGEMENTS

LIST OF FIGURES

\subsection{INCENTIVE FOR RESEARCH}

2.0 INTRODUCTION

\subsection{LOCAL MELTING PROCESSES}

2.2 ALBATION

2.3 BATCH-MELT INTERFACE REACTIONS

3.0 FOAM FORMATION: THEORY

4.0 Potential Mitigation TeChNiQues

5.0 "SYSTEMS APPROACH"

6.0 SUMMARY

7.0 OBJECTIVE

8.0 REFERENCES 
Immobilization Technology Section

\section{LiST OF FigURES}

Figure 1. Cross Section of Batch Pile Floating on Molten Glass.

Figure 2. Cross Sectional View of a Molten Batch Pile at $1540^{\circ} \mathrm{C}$ Furnace Temperature.

Figure 3. Schematic of Two Overlapping Processing Leading to Foam Formation.

Figure 4. Potential Valleys for Frit Development to Mitigate Foam.

Figure 5. DTA/TGA Run of DWPF MB2 Dried Sludge with 5.15\% Sugar.

Figure 6. DTA/TGA Run of DWPF MB2 Dried Sludge without Sugar. 
Immobilization Technology Section

Savannah River Technology Center

Rev. 0

Westinghouse Savannah River Company

This page intentionally left blank. 


\subsection{INCENTIVE FOR RESEARCH}

The objective of this research is to enhance the basic understanding of the role of glass chemistry, including the chemical kinetics of pre-melting, solid state reactions, batch melting, and the reaction pathways in glass and/or acid addition strategy changes on the overall melting process for the Defense Waste Processing Facility (DWPF) Macrobatch 3 (MB3). More specifically, by controlling the chemistry of the incoming feed materials (e.g., in particular the frit composition for a given sludge) or by adjusting chemical processing strategies (e.g., formic or nitric acid relative to the current flowsheet), the conversion rate of slurry fed raw materials into a liquid state can be increased. By altering the reaction pathway within the cold cap, intermediate reaction products and/or the development of an insulating foamy layer which can impede the melting rate can be avoided. If successful, the result is an enhanced melting process which increases throughput without compromising the quality of the final waste form or product.

Direct quantitative measurement of melting rates and/or reaction kinetics will bring important benefits for improving glass formulation and melter design strategies. These data may eventually permit the modeling of the chemical kinetics of pre-melting solid state reaction, batch melting, and reactions in glass. The data generated will result in improved melting efficiencies translating into higher throughput for the Department of Energy's (DOE) melters. Increased melting efficiencies decrease overall operational costs by reducing the immobilization campaign time for a particular waste stream. For melt rate limited systems, a small increase in melting efficiency translates into significant savings by reducing operational costs. Assuming that the DWPF is melt rate limited and a fixed annual operating cost of approximately $\$ 140$ million per year, for every $1 \%$ increase in throughput as a result of increased melting efficiency an estimated $\$ 42$ million cost avoidance would result over the scheduled mission for high-level waste vitrification. The benefit of increased melting efficiencies and the resulting cost avoidance could be applied to other DOE vitrification facilities including future missions at Hanford and Idaho (adjustments for annual operating cost would be required for each mission).

This project will enhance the basic understanding of the role of glass chemistry and/or chemical processing changes on the overall melting process for MB3. Basic technical issues regarding the batch-to-glass conversion process will be addressed for a specific alkali borosilicate glass system. Use of this particular glass forming system is applicable to both DOE and commercial vitrification programs. The DWPF and West Valley Nuclear Services are currently generating 
high-level waste glasses using alkali borosilicate frits. Hanford and Idaho National Environmental and Engineering Laboratory (INEEL) may ultimately use an alkali borosilicate system to immobilize their high-level and/or low-level waste streams. Therefore, enhancing the basic understanding of the role of glass chemistry on the overall melting process has significance not only to DOE but to the commercial sector as well.

\subsection{INTRODUCTION}

Glass melting, or conversion of batch to melt, involves several physical and chemical processes. The melting process is typically defined by three inter-dependent stages: (1) batch reaction, (2) fining, and (3) homogenization. The response of the slurry or batch to rising temperatures (melting reactions) has an impact on the latter stages of melting and hence the efficiency of the overall melting process (Peeler 1993b). Smith et al (1996) describe the major stages and reaction sequences a liquid slurry goes through as it is progressively transformed into a molten glass. The initial liquid slurry boils, loses water, and congeals. The congealed slurry continues to lose free water through vents formed while the slurry was congealing and through shrinkage cracks that form during drying. At the dry stage, salt eutectics begin to melt, hydroxides break down, and batch reactions such as those between reducing agents, nitrates, and nitrites are initiated producing initial liquid phases. As the temperature increases further, pores in the batch blanket are closed as a result of increased liquid phase production resulting in the accumulation of gaseous reaction products (bubbles). As further heating greatly increases the amount of melt increases and lowers its viscosity, gas bubbles may coalesce and escape through holes around the edges of the cold cap.

For dry feed systems, similar type of reactions occur. Once introduced into the melter, the batch initially responds to increasing temperature through dehydration, thermal decomposition, and various phase transitions of the initial granular components. As the batch temperature continues to rise, solid state reactions produce intermediate reaction products, a process which is highly dependent on local environments in the batch (Sheckler 1990 and Peeler 1993a). The formation of an initial liquid phase (of carbonates, nitrates, nitrites, sulfates, etc.) initiates vigorous solid/liquid reactions as the initial liquid phase(s) coats the remaining refractory oxides of the batch. As the fraction of the glass forming phase increases, the glass forming phase becomes a highly viscous interconnected matrix with suspended refractory particles (e.g., $\mathrm{SiO}_{2}$ ). Dissolution of these particles is controlled by diffusion within the melt. 
As previously mentioned, the response of the batch to rising temperatures (melting reactions) has an impact on the latter stages of melting and hence the efficiency of the overall melting process (Peeler 1993b). Although the melting process has been defined by three inter-dependent stages, the primary focus of this project is on the processes occurring within the initial stage (batch reaction) and their ultimate effect on melt rate.

Three key areas have been identified in this initial stage: (1) local melting processes, (2) ablation, and (3) the batch/melt interface reactions. These stages are usually discussed in the context of commercial melting based on dry feeding. Although DWPF is slurry fed, the primary reactions including the local melting processes and the batch/melt interface reactions are similar; thus a general discussion is warranted. The one area that may not be warranted for liquid-fed melters is the ablation process. The three key areas of this initial melting stage are briefly discussed below.

\subsection{Local Melting Processes}

Glass batch, either slurry or dry feed, responds to heating by producing new solid, liquid, and gas phases. The reactions involve intermediate products and complex mechanisms, in which gas evolution, liquid formations, surface phenomena and diffusion play a role (Hrma 1988). The reaction rates and paths are affected by raw material chemistry, particle size distribution, thermal profiles, and sample size and geometry. Some parameters significantly differ among laboratory tests or melter situations. Thus, it is important to study the melting process at the local level and to understand the effects of the environment and geometrical configuration on the evolution of local reactions.

Past studies of localized reactions are too extensive to discuss here but have been highlighted by Hrma (1988 and 1990). Generally, these studies have enhanced the understanding of the complex processes involved with glass melting but have gained little ground toward increasing model accuracy to predict melting phenomena. Because of the complexities involved, several analytical techniques should be used to characterize the local processes leading from batch to homogeneous glass and to link the bulk melt with reactions at these interfaces.

\subsection{Ablation}


Figure 1 (Woolley 1991) shows a cross-sectional view of a "reacting" batch pile on a molten glass surface. Four distinct regions are shown: (1) a bubbly liquid layer on the batch surface, (2) a bubbly liquid layer at the batch-melt interface, (3) a layer of solid particles wet with molten salts, and (4) cold, unreacted batch. Run-off of the "bubbly layer" from the batch surface (controlled by ablation) and the batch-melt interface (controlled primarily by convection currents) strongly influence the overall melting rate. This section addresses only ablation (or liquid run-off from the batch surface) which may not be relevant for DWPF (or other liquid-fed melters) but may be applicable to dry fed melters (e.g., direct vitrification of INEEL calcine). Processes occurring at the batch-melt interface are discussed in a following section (Batch-Melt Interface Reactions).

Once batch is charged into a melter, exposure to radiant heat (such as lid heaters) converts the outermost surface layer into a liquid phase containing a large fraction of undissolved refractory particles and gaseous inclusions. This heterogeneous liquid layer forms shortly after the batch is charged, depending on the heat flux absorbed by the surface. If permissible (governed by batch topography/geometry and liquid viscosity), the liquid layer runs off the batch pile "exposing" unreacted or partially reacted batch which continues to melt due to radiant heat. This continuous process can maximize the rate of batch-to-glass conversion if properly "controlled". Increases in thickness of the liquid layer can create an effective thermal insulator (primarily due to the presence of bubbles), especially if flow is restricted (i.e., not allowed to run off). Therefore, ablation strongly influences the melting rate of the batch pile from above.

Hammel (1986) monitored the temperature gradient in a hemispherical soda-lime-silica batch placed in a furnace at $1540^{\circ} \mathrm{C}$ (Figure 2). At any given time, the temperature profile was approximately $1120^{\circ} \mathrm{C}$ on the surface, $200^{\circ} \mathrm{C} 13 \mathrm{~mm}$ below the surface, and essentially room temperature $26 \mathrm{~mm}$ below the surface. This illustrates the effective insulating properties of the bubbly layer and the unreacted batch. It also stresses the importance of effective heat transfer to the batch, one of the major problems in the batch-to-glass conversion process. Factors affecting heat transfer to the batch include batch topography /geometry, temperature or heat flux, and batch chemistry. 
Immobilization Technology Section

WSRC-RP-2001-00351

Savannah River Technology Center

Rev. 0

Westinghouse Savannah River Company

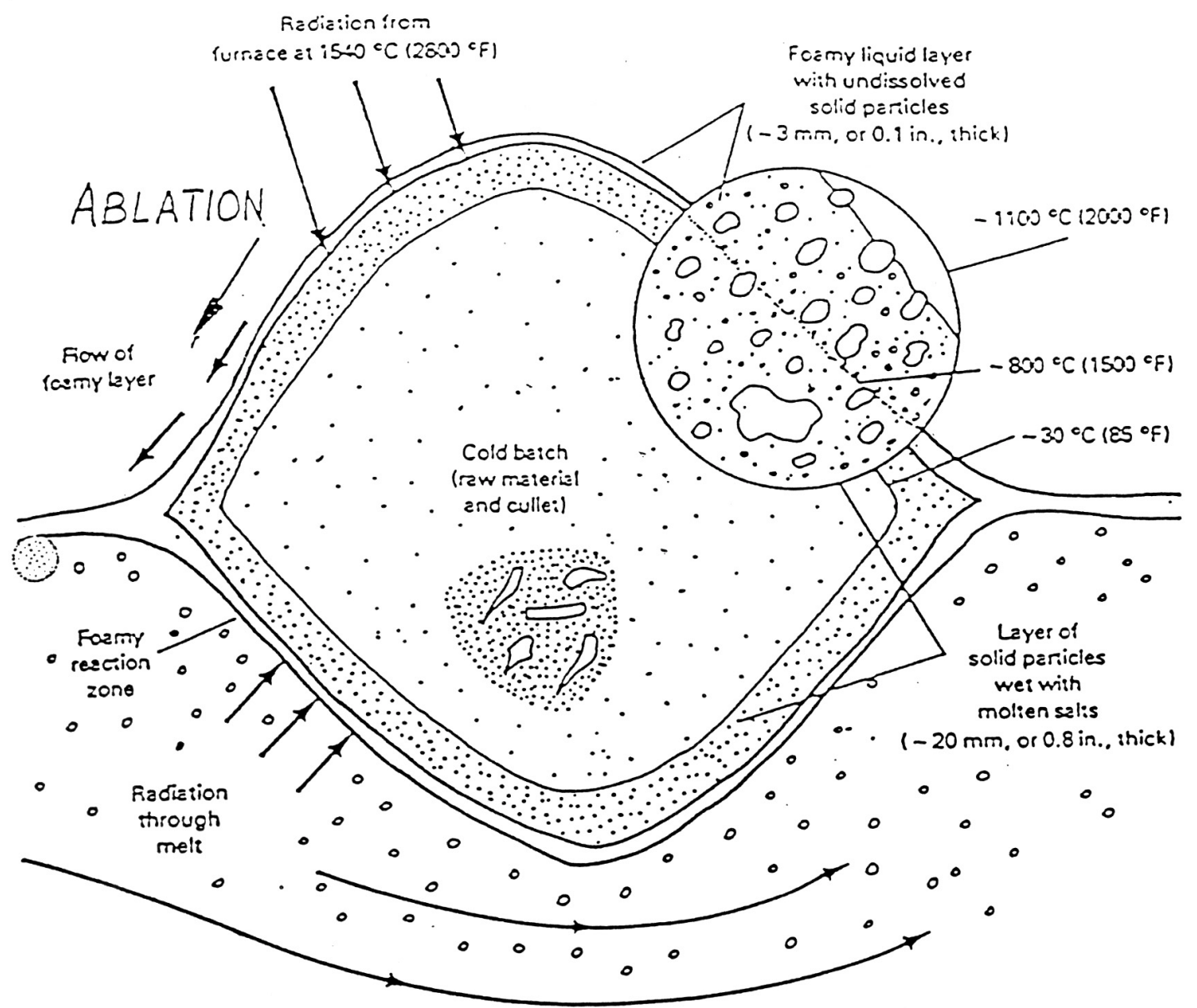

Slow flow of ho: molien glass

Figure 1. Cross Section of Batch Pile Floating on Molten Glass.

(Woolley 1991) 


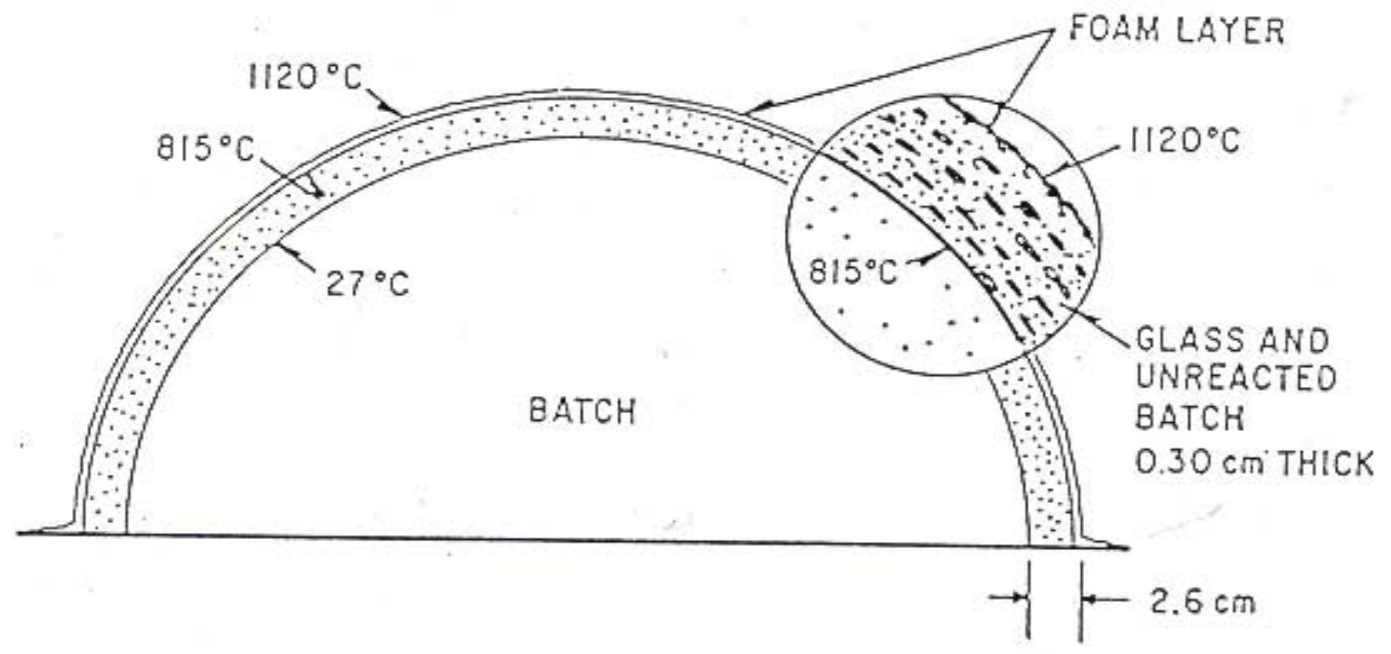

Figure 2. Cross Sectional View of a Melting Batch Pile at $1540^{\circ} \mathrm{C}$ Furnace Temperature. (Hammel 1986)

\subsection{BATCH-MELT INTERFACE REACTIONS}

The formation of a heterogeneous bubbly layer can also occur at the batch-melt interface as the granular materials are converted into a melt (see Figure 1). This bubbly layer is typically characterized by a large fraction of undissolved refractory particles and gaseous inclusions. As in the ablation process, the microstructural characteristics and behavior of this layer influence the melting rate of the batch. The rate at which heat is transferred across the interface is related to the batch-to-melt conversion rate or melt rate (Hrma 1990). If there were no impediment of heat transfer to the batch, reaction kinetics would limit the melting rate.

The formation of the thermally insulating bubbly layer (primarily due to the gaseous inclusions) reduces heat transfer through the molten glass to the batch as described above. Natural or forced convection within the molten glass and the buoyancy force associated with the low density of the bubbly melt enhances the removal of this layer (e.g., viscosity of the molten glass pool may be a key parameter with respect to enhancing melt rate). If steady-state conditions exist between the 
removal and formation of this foamy layer, a steady thickness may be maintained which continually impedes melt rate.

As discussed in the previous sections, the melting process is an extremely complex process dependent upon various melter operating conditions and physical/chemical properties of the feed. Given that, one needs to establish or identify the relevant processes that impede melt rate for a given system and focus research and development efforts on potential mitigation techniques. In this study, the primary focus is on the propensity of batch expansion and/or the formation of a foamy layer and its potential to negatively impact melt rate. It is assumed that the formation of a stable, foamy layer in the batch will directly impede melt rate and that its formation can be monitored and/or predicted through a suite of small scale tests.

Inexpensive and rapid small-scale testing is needed to estimate melting rate and behavior of prospective feeds to the DWPF melter. Previously, the only approach to fulfill this need was expensive large-scale melter runs which are cumbersome and typically limited in focus and/or number. As previously noted, due to the complexities involved, several analytical techniques should be used to characterize the local processes leading from batch to homogeneous glass. Even though a suite of small-scale tests are typically utilized to assess melt rate, one must account for any scaling effects as projections to larger systems are made.

\subsection{FOAM FORMATION: THEORY}

Historically, foaming in glass has been divided into two categories: (i) feed (batch) expansion which is a bulk foam resulting from batch reactions during melting and (ii) molten glass foam which is a surface foam occurring after the batch reactions are complete (Smith 1995). Batch expansion has been observed in simulated nuclear waste glass during gas generation in the presence of an interconnected glassy phase (Vienna 1994 and Ahn 1986). Batch expansion results from reaction gases trapped in an early glass forming melt which has a high viscosity and releases gases slowly. The formation of this foamy layer can slow the melting rate by insulating the cold cap from the melt resulting in process interruptions (e.g., feeding halted to burn off the cold cap).

Kim (1990) indicated that batch expansion will occur if three conditions are simultaneously met: (1) gas is generated, (2) a high-viscosity melt has formed, and (3) the melt is sufficiently 
interconnected. Hence, batch expansion can be affected or minimized by: (1) a shift in the gas evolution interval (e.g., due to a redox / acid addition strategy change), (2) a shift in the viscous melt generation interval (e.g., due to a frit composition change) or (3) a change in the melt fraction at which foaming commences (primarily controlled via frit composition changes).

Goldman (1986) addressed the causes of foaming and the mechanisms that stabilize foam for alkali-iron-borosilicate glasses melted from liquid slurries. His work (which focused on the production and removal of bubbles within a given melt; not batch expansion) demonstrated that reboil pressure and foaming tendency observed in melter glasses were positively correlated. That is, highly oxidized glasses (lacking ferrous iron) collected from melter tests having significant foaming were determined to have the highest reboil pressures (directly related to the amount of oxygen and water dissolved in the melt). The results suggested that the oxygen was associated with redox species such as manganese, cerium and chromium (no ferrous iron detected).

Goldman et al. (1986) also evaluated the foam stability pointing out that foaming can be diminished by including reducing agents in the liquid slurry (either in the processed waste, glass forming chemicals, or as separate additives such as sugar). A reduced glass contains less oxygen and should therefore have a lower foaming tendency. However, this alone can not explain the elimination of foaming. For example, a conversion of $0.1 \mathrm{wt} \%$ ferric to ferrous iron in a glass can evolve a volume of oxygen greater than the entire melt volume. This conversion does not require a significant change in redox or temperature. Therefore, even under reducing conditions, the source of oxygen available to generate a stable foam exists. Goldman et al. (1986) did indicate that foams generated under reducing conditions were unstable (perhaps due to $\mathrm{H}_{2} \mathrm{O}$ ). Bubbles that formed in the bulk melt ruptured when they reached the melt surface. It was proposed that under reducing conditions, proportionally more water vapor is released which destabilizes the foam either by surface tension or viscosity effects.

Historically, formic acid has been used as a reductant for nitrates, nitrites, and higher valent transition metals in the glass melt. Reduction causes transition metals to release gas in the cold cap and after incorporation into the glass. If not reduced at low temperatures, transition metals will release a large volume of gas as equilibrium is approached in the melt. However, overly reduced melts must be avoided to preclude the separation of sulfides and elemental metals (Bickford 1986a and Bickford 1986b). 


\subsection{Potential Mitigation TeChniQues}

Figure 3 provides a conceptual schematic of the two overlapping processes (gas generation and a high viscosity, interconnected glass phase) leading to foam formation. Typical sources for gas generation include decomposition reactions (e.g., nitrate destruction liberating $\mathrm{NO}_{\mathrm{X}}$ and $\mathrm{CO}_{2}$ and/or decomposition of intermediate reaction products formed during the batch-to-glass conversion process with the cold cap) and/or redox reactions (e.g., manganese and/or iron reduction liberating oxygen). The formation of a highly viscous liquid phase can be the result of frit softening and/or the reactions between the frit and the waste (both a function of frit composition and temperature). In Figure 3, it is speculated that the overlap of the temperature at which gas is liberated as a result of redox reactions with the temperature of frit softening could lead to foam formation. This scenario is only hypothetical given the complex nature of the melting kinetics involved.

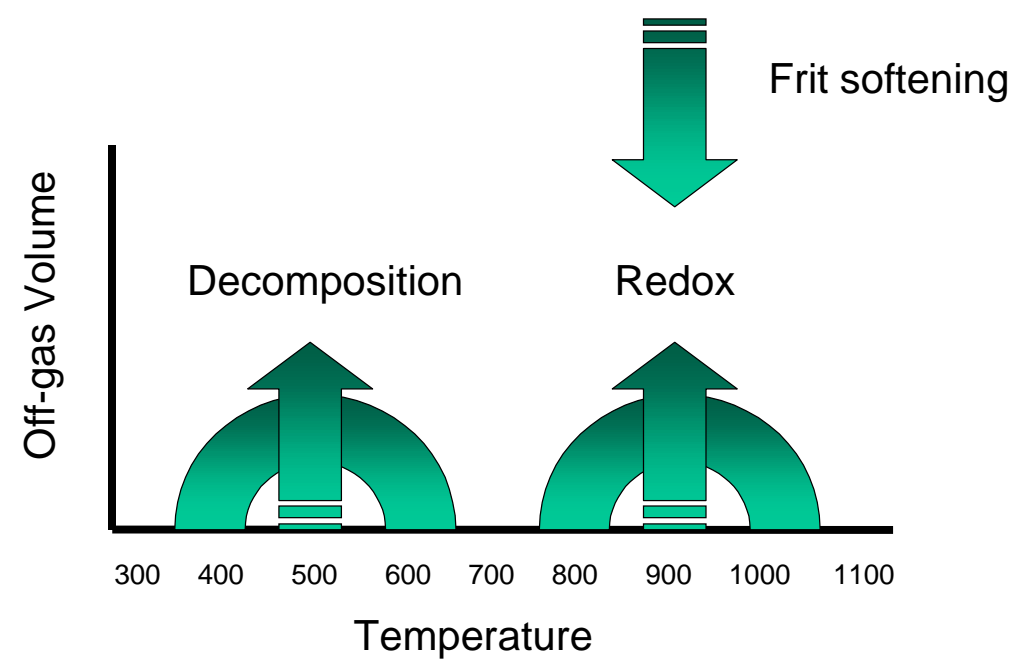

Figure 3. Schematic of Two Overlapping Processes Leading to Foam Formation. (off-gas related reactions may be overlapped and continuous over a broad temperature range)

To minimize the potential for foam formation (and ultimately to enhance melt rate) one must avoid or minimize the overlap of these two phenomena. To accomplish this, one can either adjust the temperature region over which the off-gas related processes occur or adjust the viscosity temperature relationship for the liquid phase. To affect the former, the addition of reductants (e.g., sugar) and/or acid addition strategies have been utilized. The latter (viscosity) is primarily controlled through frit formulation changes. 
Figure 4 provides a schematic of how frit compositional changes may avoid or minimize foam potential (i.e., altering the softening point and viscosity of the liquid phase). That is, one could alter the frit composition so as to soften or melt in one of the valleys where off-gas generation is lower. This latter statement assumes that the softening point of the frit (producing a high viscosity liquid phase) does not overlap with gas evolution from the decomposition reactions (e.g., nitrates).

The initial frit arrow (located in the $700^{\circ} \mathrm{C}$ temperature range) suggests that one may formulate a frit that "softens" after decomposition reactions are complete but prior to the onset of redox reactions that liberate $\mathrm{O}_{2}$. In this case, one would theoretically liberate the gas generated via decomposition reactions prior to the formation of a high viscosity liquid phase. Prior to the onset of $\mathrm{O}_{2}$ liberation from redox ${ }^{1}$, the melt would form a low viscosity liquid which would minimize the entrainment of $\mathrm{O}_{2}$ from redox thereby minimizing foam potential. Again, these scenarios are strictly hypothetical given the complex nature of the melting kinetics involved. For example, the discussion ignores any potential for the reactions that occur between the frit and the waste during heat up to generate a high viscosity liquid phase and assumes that the off-gas related reactions are independent (do not overlap and not continuous) over a broad temperature range and are not influenced by compositional changes. However, the discussions, which are intended to provide insight into the potential mitigation options to minimize foam formation for a given system, are useful when considering the impacts of frit composition and/or acid addition strategy changes on potential to mitigate foam formation for MB3.

\footnotetext{
${ }^{1}$ Oxygen liberation via reduction is a continuous process over a given temperature range.
} 


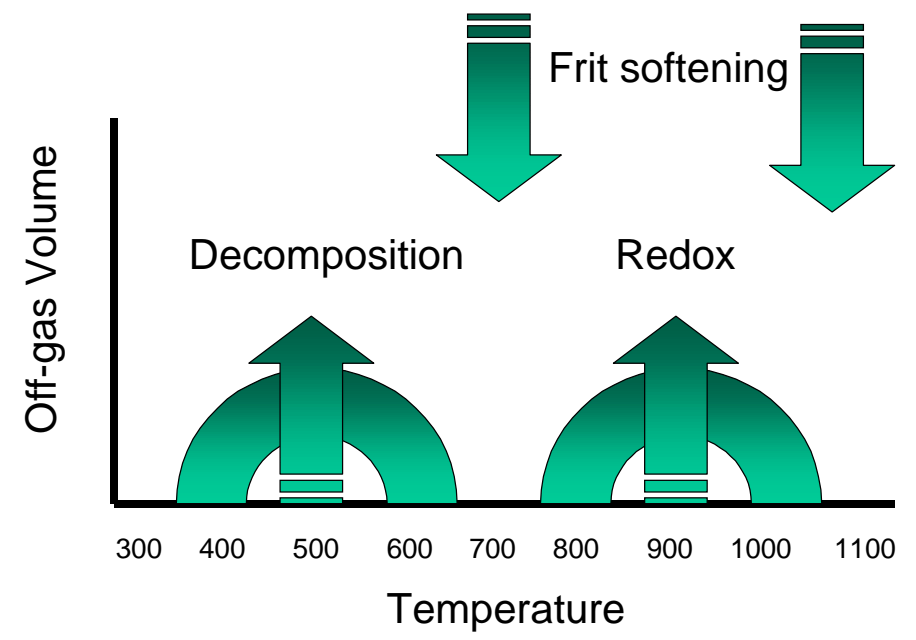

Figure 4. Potential Valleys for Frit Development to Mitigate Foam.

Stone and Lambert (2000) provided DTA/TGA/MS data for DWPF MB2 sludge which indicated some of the off-gas related phenomena for that system. Figures 5 and 6 show the off-gas related data as a function of temperature for MB2 sludge with and without sugar, respectively. These plots not only provide an indication of the off-gas volumes as a function of temperature (indicated by the peaks and valleys 2 but also the effect of sugar as a reductant impacting the off-gas behavior. It should be noted that for MB2 there are regions where off-gas volumes are relatively low in both DTA/TGA runs.

\footnotetext{
${ }^{2}$ Peak heights in Figures 5 and 6 do not give a direct indication of the volume of gas liberated as a function of temperature. As temperatures increase, small quantities of gas can generate a large volume. For example, a conversion of $0.1 \mathrm{wt} \%$ ferric to ferrous iron at high temperatures can evolve a volume of oxygen greater than the entire melt volume.
} 
Immobilization Technology Section

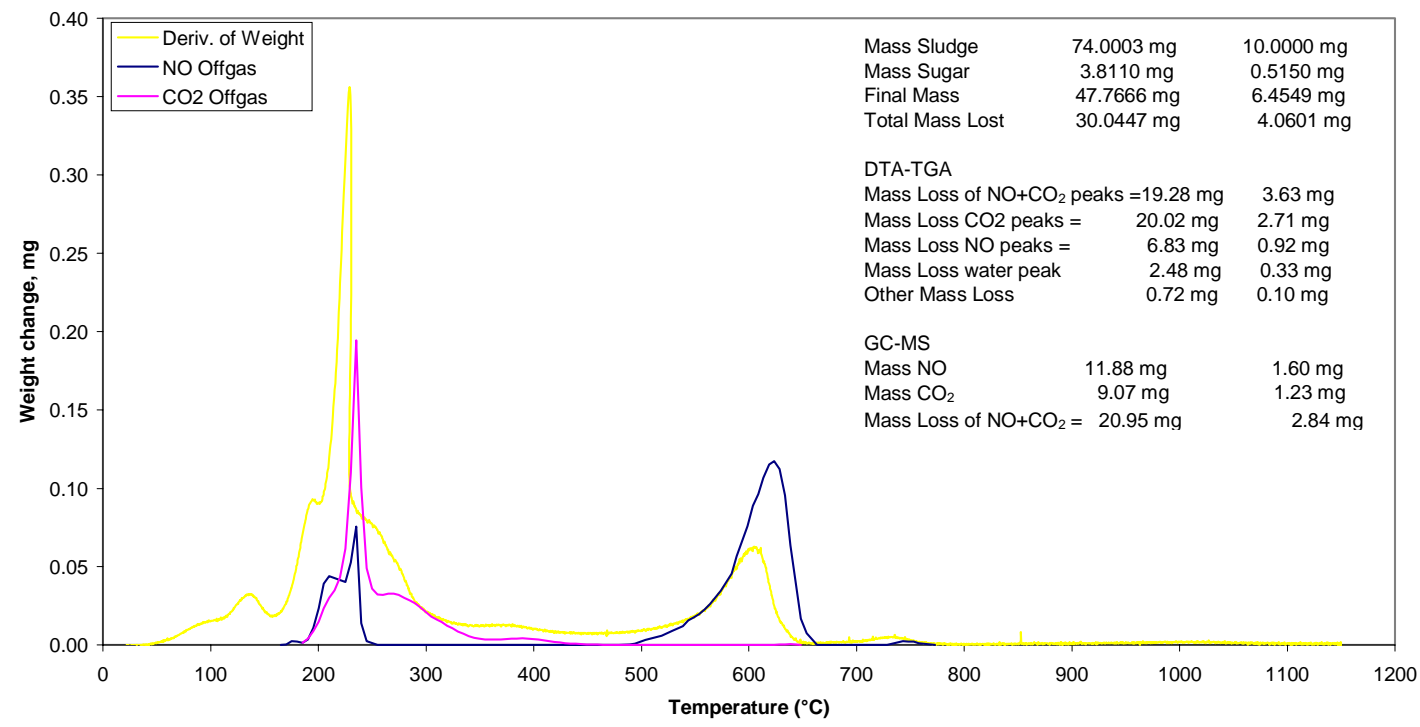

Figure 5. DTA/TGA Run of DWPF MB2 Dried Sludge with 5.15\% Sugar.

(run conditions under $79 \% \mathrm{He}$ and $21 \% \mathrm{O}_{2}$ )

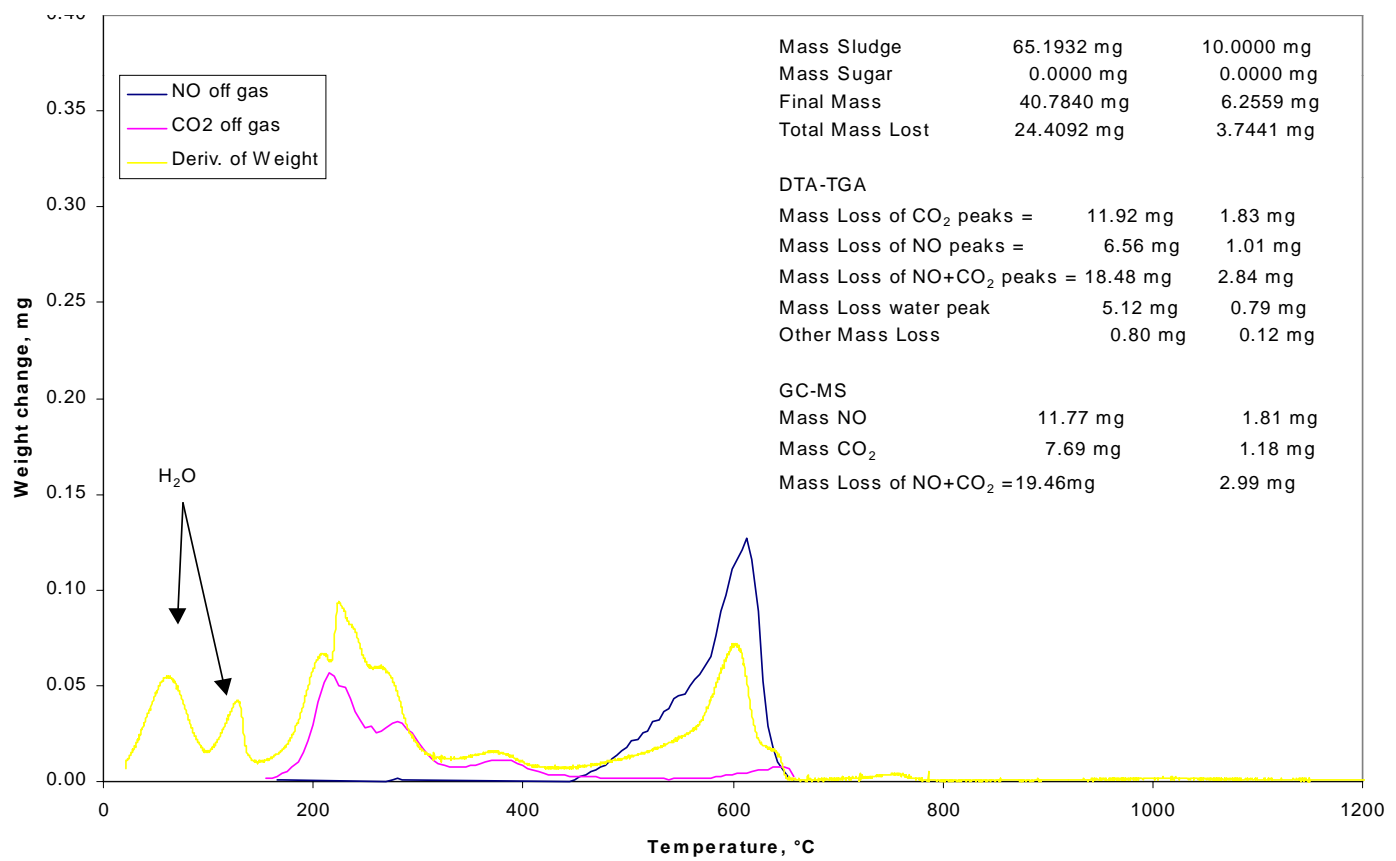

Figure 6. DTA/TGA Run of DWPF MB2 Dried Sludge without Sugar.

(run conditions under $79 \% \mathrm{He}$ and $21 \% \mathrm{O}_{2}$ ) 
In terms of frit compositional adjustments, the second scenario (see Figure 4) is associated with making a more "refractory" frit (i.e., higher melting point frit). In this case, the onset of the initial high viscosity is delayed until both the decomposition and redox reactions are complete. In the absence of a high viscosity liquid phase, gases generated are not trapped and melt rate is not impeded (assuming a direct correlation with the formation of a foam layer and melt rate). Again, this scenario is hypothetical given the complex nature of the melting kinetics involved. An alternative to changing the composition of a pre-fabricated frit to fit within one of the aforementioned off-gas valleys is the use of batch chemicals. This typically results in a delay of the formation of an initial liquid phase making this option more similar to a "refractory" frit option.

\section{0 "SYSTEMS APPROACH"}

Compositional adjustments to candidate frits must be tempered by the need to not only meet increased production rates but also (and perhaps more importantly in the case of nuclear waste glasses) product performance (e.g., durability) and other processing (e.g., viscosity, liquidus, and electrical conductivity) requirements. This balanced or "systems approach" has been described by Jantzen (1985). Smith (1995) also indicated that the effects of frit composition on melter feed and melt processing, glass acceptance and waste loading are of practical interest in understanding the trade-offs associated with the competing demands placed on frit composition. 


\subsection{SUMMARY}

Glass melting is a complex process that involves a number of reactions and transformations, and its rate or behavior can only be described considering all related processing properties. Given that, one needs to establish or identify the relevant processes that impede melt rate for a given system and focus research and development efforts on potential mitigation techniques. Consequently, it is necessary to identify possible laboratory test methods to evaluate these pertinent processing properties. It has been suggested that the development of appropriate laboratory test methods should be preceded by the understanding of the basic processes compromising the cold cap melting.

In this study, the primary focus is on the propensity of batch expansion or the formation of a foamy layer and their potential to negatively impact melt rate. It is assumed that the formation of a stable, foamy layer in the batch will directly impede melt rate and that its formation can be monitored and/or predicted through a suite of small scale tests. The effects of various melter operating conditions and physical/chemical properties of the feed on the melting rate needs to be clearly established.

Batch expansion or melt foaming can be minimized if the high viscosity melt temperature region does not coincide with that of gas evolution. Potential foam mitigation techniques include frit compositional changes and/or acid addition strategy changes (relative to the current flowsheet).

To make educated recommendations on such adjustments, a fundamental understanding of the mechanisms leading to foam must be understood including the reaction pathway or kinetics of the glass system, off-gas behavior as a function of redox, and glass / frit viscosities. Without a detailed knowledge of these fundamental parameters, changes to either redox or frit formulation will be "trial and error". This being the case, one would tend to focus on one of the parameters leaving the other "fixed" and hope to bound the effect. In the event that both frit compositional changes as well as redox and/or acid addition strategy changes are independently identified that improve melt rate, these effects may not be additive. Therefore, prior to recommending both a compositional change with a redox/acid addition change, the effects must be jointly evaluated using the appropriate test methodology. This assumes that the test methodology or suite of tests being used to assess melt rate directly translates to a full scale system. 


\subsection{OBJECTIVE}

The objective of this research is to enhance the basic understanding of the role of glass batch chemistry (more specifically via control of frit composition) and/or changes in chemical processing strategies on the overall melting process for MB3 (DWPF sludge-only processing). Through control of batch chemistry, cold cap reactions can be altered which may result in higher melter throughput. For melt rate limited systems, a small increase in melting efficiency translates into substantial hard dollar savings by reducing operational costs without compromising the quality of the final waste form or product.

The specific goal of this research is to improve melt rate for Macro-batch 3 (MB3) in an effort to demonstrate that production goals can be met (or exceeded) and/or "sprint" capabilities do exist. In doing such, it is anticipated that a fundamental understanding of the impact of feed parameters (assuming a fixed set of melt conditions) on the local melting processes and reactions at the batch-melt interface will be developed. Although primary focus is to improve melt rate for a specific macrobatch, a "systems approach" will be utilized. Proposed change to frit compositions will be tempered by current THERMO model predictions in terms of SME acceptability (Jantzen et al. 1995 and Brown and Postels 1996). If model predictions do not allow for acceptance, one of two options will be utilized. The potential frit composition will not be considered (Option \#1) or a technical basis must be developed prior to an ultimate recommendation (Option \#2). Recommendations for redox and/or acid addition strategy changes will be tempered by a thorough assessment of related safety issues. If the systems approach or a thorough assessment of safety related issues are not utilized, one could make an off-spec glass faster or compromise melter processing and/or the safety basis. Regardless of whether a potential frit composition change is acceptable or not in terms of predictions, it is recommended that prior to DWPF implementation all properties should be assessed to ensure the proposed compositional changes do not invalidate current model predictions (i.e., the proposed glass composition is still within the compositional envelope over which the models were developed). It should be noted that frit development activities were directed solely toward MB3 and the use of a specific frit composition with another sludge batch may not be warranted. 
This work is being performed in response to Technical Task Request (TTR) \#HLW/DWPF/TTR00-0044, DWPF Macrobatch 3 Melt Rate Study. The foundation for the test protocols and methodology were established through the recent work by Stone et al. (2000) for MB2.

\subsection{REFERENCES}

Ahn, J.S. and P. Hrma, 1986. "Effect of Heat Pretreatment on Foaming of Simulated Nuclear Waste in a Borosilicate Glass Melt," Advances in Ceramics, 20: 181-190.

Bickford, D.F. and R.B. Diemer 1986a. "Redox Control of Electric Melters with Complex Feed Compositions: I. Analytical Methods and Models," J. Non-Cryst. Solids, Volume 84, 276 - 284 (1986).

Bickford, D.F. and R.B. Diemer 1986b. ““'Redox Control of Electric Melters with Complex Feed Compositions: II. Preliminary Limits for Radioactive Waste Glasses," J. Non-Cryst. Solids, Volume 84 (1986) 285 - 291.

Brown, K.G. and R.L. Postles. 1996. SME Acceptability Determination for DWPF Process Control (U), WSRC-TR-95-0364, Revision 3.

Goldman, D.S. 1986. "Melt Foaming, Foam Stability, and Redox in Nuclear Waste Vitrification”, J. Non-Cryst. Solids, Volume 84 (1986) 292 - 298.

Goldman, D.S. D.W. Brite, and W.C. Richey (1986). "Investigation of Foaming in Liquid-Fed Melting of Simulated Nuclear Waste Glass" J. Amer. Ceram. Soc., Volume 69 (5) pp. 413 - 417.

Hammel, J.J., 1986. "Some Aspects of Tank Melting," Advances in Ceramics, Vol. 18, Commercial Glasses, D.C. Boyd and J.F. MacDowell, eds., 177-85 (1986).

Hammel, J.J. and J.D. Mackenzie, 1981. "Glass Melting Enhancement by Toroidal Batch Shaping," US Patent Number 4,282,023, August 4, 1981.

Hrma, P., 1988. "Complexities of Batch Melting," Advances in Fusion of Glass, pp. 10.1- 10.18, American Ceramic Society, Westerville, Ohio.

Hrma, P., 1990. "Melting of Foaming Batches: Nuclear Waste Glass," Glastech. Ber. 63K, 360 369.

Jantzen, C.M. 1985. "Systems Approach to Nuclear Waste Glass Development”, DP-MS-85-72. E.I du Pont de Nemours and Company, Savannah River Laboratory, Aiken, SC.

Jantzen, C.M., 1988. "Glass Compositions and Frit Formulations Developed for DWPF," DPST88-952, Technical Division, Savannah River Laboratory, Aiken, SC.

Jantzen, C.M., J.B. Pickett, K.G. Brown, T.B. Edwards, and D.C. Beam. 1995. Process/Product Models for the Defense Waste Processing Facility (DWPF): Part I. Predicting Glass Durability 
from Composition Using a Thermodynamic Hydration Energy Reaction Model (THERMO) (U), WSRC-TR-93-673, Rev. 1, Volume 1.

Kim, D.S. and P. Hrma, 1990. "Volume Changes During Batch to Glass Conversion," Ceramic Bulletin, 69 [6]: 1039-1043

Kim, D.S. and P. Hrma, 1994. "Laboratory Studies for Estimation of Melting Rate in Nuclear Waste Glass Melters," Ceramic Transactions, Environmental and Waste Management Issues in the Ceramic Industry II, Volume 45, pp. 409 - 419.

Peeler, D.K., 1993a. "The Effect of Initial Particle Size Distributions on the Melting Kinetics of Soda-Lime-Silica Glasses by In-Situ High-Temperature X-Ray Diffraction,” Ph.D. Dissertation, Clemson University.

Peeler, D.K., T.D. Taylor, and D.R. Dinger, 1993b. "The Effect of Initial Particle Size Distributions on the Melting Kinetics of Soda-Lime-Silica Glasses," Ceramic Transactions, Advances in the Fusion and Processing of Glass, Volume 29, pp. $151-164$.

Sheckler, C.A., and D.R. Dinger, 1990. "Effect of Particle Size Distribution on the Melting of Soda-Lime-Silica Glass," Journal of the American Ceramic Society, 73 [1]: 24-30.

Smith, P.A., J.D. Vienna, and P. Hrma, 1995. "The Effects of Melting Reactions on Laboratory-Scale Waste Vitrification," J. Mater. Res., Volume 10, No. 8, pp. 2137 - 2149.

Smith, H.D., G.L. Smith, E,M. Tracey, and D.K. Peeler, "Effect of Cold Cap Chemistry on Waste Melter Vitrification Kinetics," Proceeding of the International Topical Meeting on Nuclear and Hazardous Waste Management, pp. 2324 - 2329 (1996).

Stone, M.E. and D.P. Lambert 2000. "DWPF Macrobtach 2 Melt Rate Tests", WSRC-TR-200000395, Westinghouse Savannah River Company, Savannah River Technology Center, Aiken, SC.

Vienna, J.D., P.A. Smith, D.A. Dorn, and P. Hrma, 1994. "The Role of Frit in Nuclear Waste Vitrification," Environmental and Waste Management Issues in the Ceramic Industry II, D Bickford et al. eds., Volume 45, American Ceramic Society, Westerville, Ohio.

Woolley, F.E., 1991. Melting/Fining, "Ceramics and Glasses", Engineering Materials Handbook, Volume 4, S.J. Schneider, Jr., Volume Chairman, ASM International. 
Other Relevant References:

Anderson, L.D., T. Dennis, M.L. Elliott, and P. Hrma, 1994. 'Waste Glass Melting Stages," Ceramic Transactions, Volume 39, pp. 213- 220.

Bickford, D.F., P. Hrma, and B. W. Bowan II, 1990. "Control of Radioactive Waste Glass Melters: II, Residence Time and Melt Rate Limitations," Journal of the American Ceramic Society, 73 [10]:2903-2915.

Bodalbhai, L. and P. Hrma, 1986. '"The Dissolution of Silica Grains in Isothermally Heated Batches of Sodium Carbonate and Silica Sand," Glass Technology, 27 [2]: $72-78$.

Boger, D.V. and K. Walters, 1993. Rheological Phenomena in Focus, Elsevier, New York.

Bunting, J.A. and B.H. Bieler, 1969. "Batch-Free Time Versus Crucible Volume In Glass Melting," Ceramic Bulletin, 48 [8].

Cable, M., and M.Q. Siddiqui, 1980. "The Replacement of Soda Ash by Caustic Soda in laboratory Glass Melting Trials," Glass Technology, 21 [4]: 193 - 198.

DOE, 1995. Research, Development, and Demonstration of New and Advanced Technology for the Glass Industry, United States Department of Energy, Solicitation Number DE-PS07-95ID13346, Idaho Operations Office, February, 1995.

Erickson T.D., 1974. "A Gradient Furnace Method to Determine the Reaction Rates of Glass Raw Materials," 35th Annual Conference on Glass Problems, Collected Papers pp. 131-146.

Faber, A.J., R.G.C. Beerkens, and H. de Waal, 1992. "Thermal Behavior of Glass Batch on Batch Heating," Glastech. Ber. 65.

Hayes, J.C., 1988. "Laboratory Methods To Simulate Glass Melting Processes," Advances in Fusion of Glass, pp. 14.1 - 14.8, American Ceramic Society, Westerville, Ohio.

Hrma, P., 1970. "Dissolution of a Solid Body Governed by Surface Free Convection," Chem. Eng. Sci. 25: 1679-1688.

Hrma, P., and A. Sramkova, 1973. "The Rate of Dissolution of a Solid Body in Liquid Meniscus Governed by Density Free Convection," Silikaty 16 [2]: 89-102.

Hrma, P., 1973. "Dissolution of Solid Bodies Controlled by Diffusion in Free Convective Flow," Sci. Papers Prague Inst. Chem. Technol. B6, 85-88.

Hrma, P., 1976. "Stoichiometry of Chemically Reacting Mixtures," Chem. listy 70: 450-466.

Hrma, P., 1980. "Similarity of Electro-Thermo-Mechanical Processes in Modeling of the Glass Melting Process," Silikaty 24 [3]: 265-270.

Hrma, P., 1980. "A Kinetic Equation for Interaction between Grain Material and Liquid with Application to Glass Melting," Silikaty 24 [1]: 7-16. 
Hrma, P., 1982. "Thermodynamics of Batch Melting" Glastech. Ber. 55 [7] 138-150.

Hrma, P., 1983. "Criteria for Physical Modeling of Electric Glassmelting Furnaces," Journal of the American Ceramic Society, 66 [7]: 519-523.

Hrma, P., 1985. "Reaction between Sodium Carbonate and Silica Sand at $874^{\circ} \mathrm{C}<\mathrm{T}<1022^{\circ} \mathrm{C}$," ," Journal of the American Ceramic Society, 68 [6]: 337-341.

Hrma, P., 1985. "Glassmaking in 2004," 1. Journal of Non-Crystalline Solids, 73: 501-515.

Hrma, P., J. Barton and T. L. Tolt, 1986. "Interaction between Solid, Liquid and Gas During Glass Batch Melting," Journal of Non-Crystalline Solids, 84: 370-380.

Hrma, P., 1987. "Boundary Condition for Mass Transfer Across a Moving Interface," Journal of Crystal Growth, 80: 121-124.

Hrma, P., 1989. "Periodic Motion of Bubbles in Molten Glass," Glass Technology, 30 [5]: 184-189.

Hrma, P., 1989. "Bubble Removal from Glass Melts: Power-Law Model," Glastech. Ber. 62 [9]:301-311.

Hrma, P., 1990. "Batch Melting Reactions," pp. 157-178 in A. Paul, "Chemistry of Glass," Prentice Hall, London.

Hrma, P., 1990. "Model for a Steady State Foam Blanket," Journal of Colloid Interface Science, 134 [1]:161-168.

Hrma, P., C. E. Goles, and D. D. Yasuda, 1991. "Drainage of Primary Melt in a Glass Batch," Ceramic Transactions, 23: 361-367.

Hrma, P., 1993. "Processing Constraints on High-Level Nuclear Waste Glasses for Hanford Waste Vitrification Plant," Proc. 1993 International Conference on Nuclear Waste Management and Environmental Remediation, Vol. 1, pp. -403-409.

Hrma, P., and D.-S. Kim, 1994. "Sulfate Mass Balance and Foaming Threshold in a Soda-Lime Glass," Glass Technology, 35 [3]:128-134.

Ilhan, A., D.-S. Kim, and P. Hrma, 1990. Instantaneously Generated Foam and Its Applicability to Reduced Gravity, NASA Contractor Report 185208, Lewis Research Center, Cleveland, Ohio.

Jain, V. 1993. "Redox Forecasting in the West Valley Vitrification System," Ceramics Transactions, Volume 29, Advances in Fusion and Processing of Glass, edited by A.K. Varshenya, D.F. Bickford, and P.P. Bihuniak, (American Ceramic Society, Westerville, OH) pp. $523-533$.

Kim, D.-S., and P. Hrma, 1991. "Foaming in Glass Melts Produced by Sodium Sulfate Decomposition under Isothermal Conditions," Journal of the American Ceramic Society, 74 [3]:551-555. 
Kim, D.-S., and P. Hrma, 1994. "Laboratory Studies for Estimation of Melting Rate in Nuclear Waste Glass Melters," American Ceramic Society, 1994, Indianapolis, Indiana.

Lindig, M., E. Gehraman, and G. Frischat, 1985. "Melting Behavior in the Systems $\mathrm{SiO}_{2}-\mathrm{K}_{2} \mathrm{CO}_{3}-\mathrm{CaMg}\left(\mathrm{CO}_{3}\right)_{2}$ and $\mathrm{SiO}_{2}-\mathrm{K}_{2} \mathrm{CO}_{3}-\mathrm{PbO}$," Glastech. Ber. 58: [2] 127-132.

Linek, V., and P. Hrma, 1976. "Enhancement of Absorption Caused by Density Driven Convection at Gas-Liquid Interface Induced by Absorption with chemical Reaction," Chem. Eng. Sci. 31: 97-106.

Lucktong, C., and P. Hrma, 1988. "Oxygen Evolution During MnO- $\mathrm{Mn}_{3} \mathrm{O}_{4}$ Dissolution in a Borosilicate Melts," Journal of the American Ceramic Society, 71 [5]: 323-328.

Morelissen, H.W., A.H.M. Rikken, and A.J.M. Van Tienen, 1980. "Pelletized Batch: Its Manufacture \& Melting Behavior," The Glass Industry, pp. 16-20.

Thomasson, C.V., and F.W. Wilburn, 1960. "The Application of Differential Thermal Analysis and Thermogravimetric Analysis to the Study of Reactions Between Glass-Making Materials, Part 2. The Sodium Carbonate-Silica System with Minor Batch Additions," Physics and Chemistry of Glasses, 1 [2]: 52-69.

Warburton, R.S., and F.W. Wilburn, 1963. "The Application of Differential Thermal Analysis and Thermogravimetric Analysis to the Study of Reactions Between Glass-Making Materials, Part 4. The Calcium Carbonate-Silica-Alumina System," Physics and Chemistry of Glasses, 4 [3]: 91-98.

Wilburn, F.W., and C.V. Thomasson, 1958. "The Application of Differential Thermal Analysis and Thermogravimetric Analysis to the Study of Reactions Between Glass-Making Materials, Part 1. The Sodium Carbonate-Silica System," Society of Glass Technology, 42: 158-75.

Wilburn, F.W., and C.V. Thomasson, 1961. "The Application of Differential Thermal Analysis and Thermogravimetric Analysis to the Study of Reactions Between Glass-Making Materials, Part 3. The Calcium Carbonate-Silica System," Physics and Chemistry of Glasses, 2 [4]: 126-31.

Wilburn, F.W., S.A. Metcalfe, and R.S. Warburton, 1965. "Differential Thermal Analysis, Differential Thermogravimetric Analysis, and High Temperature Microscopy of Reactions Between Major Components of Sheet Glass Batch," Glass Technology, 6 [4]: 107-14.

Yasuda, D.S., and P. Hrma, 1991. 'The Effect of Slurry Rheology on Melter Cold Cap Formation," Ceramic Transactions, 23: 349-359.

Viskanta, R., 1994. "Review of Three-Dimensional Mathematical Modeling of Glass Melting," Journal of Non-Crystalline Solids, 177: 347-62.

K. F. Whittington, D. K. Seiler, J. Luey, J. D. Vienna, and W. A. Sliger, Feed Process Studies Research-Scale Melter, PNNL-11333, Pacific Northwest National Laboratory, Richland, WA (1996) 


\section{Distribution}
W. D. Kerley, 704-S
D. C. Witt, 704-1T
J. F. Ortaldo, 704-S
M. E. Stone, 704-1T
R. E. Edwards, 704-3N
D. P. Lambert, 704-1T
M. R. Norton, 704-27S
M. F. Williams, 704-1T
J. E. Occhipinti, 704-27S
D. C. Koopman, 704-1T
J. F. Sproull, 704-30S
T. K. Snyder, 773-42A
D. C. Iverson, 704-30S
J. J. Connelly, 773-41A
R. J. O'Driscoll, 704-30S
K. G. Brown, 704-1T
L. M. Papouchado, 773-A
D. R. Best, 773-41A
E. W. Holtzscheiter, 773-A
D.K. Peeler, 773-43A
R. H. Spires, 773-A
T.H. Lorier, 773-23A
D. A. Crowley, 773-43A
D. H. Miller, 786-1A
S. L. Marra, 704-1T
T. B. Edwards, $773-42 \mathrm{~A}$
D. F. Bickford, 773-43A
C. M. Jantzen, 773-A
J.C. George, 773-43A
Records (4)
VT QA File 